\title{
Grapevine yield components and composition of Isabel grape produced according to the organic and conventional systems
}

\author{
Alberto Miele \\ Embrapa Uva e Vinho, 95701-008 Bento Gonçalves, RS, Brazil
}

\begin{abstract}
There is an increasing demand for organic grapes by the juice industry of Serra Gaúcha, Brazil. This region presents a humid and hot summer, ideal climatic conditions for the development of a number of diseases. To control such diseases and problems brought about by other organisms, growers apply pesticides on the grapevines which may leave residues in grapes. However, in general, grapes produced by organic system have lower yield, but there is a lack of research data on this subject. Thus, an experiment was carried out over three years in order to compare the yield components and the physicochemical composition of the must of Isabel grapes conducted in both production systems. When the grapes were ripe, variables related to yield components were evaluated, such as the number of clusters/vine, yield/vine and weight/cluster. Then the grapes were sampled and taken to the laboratory where they were crushed and the musts were centrifuged and analyzed. The 3-year data mean were submitted to correlation analysis and Principal Component Analysis. The results show that conventional grapevines produced 2.18 times more than organic. However, the grapes from the organic system had higher density, Brix, $\mathrm{pH}$, Brix/titratable acidity ratio, $\mathrm{P}$ and $\mathrm{Mg}$ but lower $\mathrm{K}$, and $\mathrm{Ca}$ varied little between both production systems.
\end{abstract}

\section{Introduction}

The development of science and technology in the last decades had considerable effects on the increasing production of most crops. To achieve this goal, there was the contribution of many areas especially since the beginning of the $20^{\text {th }}$ century. However, sometimes this development was followed by negative impacts to the environment and to the human being, directly or indirectly. Due to this, many international institutions, officials or not, are acting today to mitigate the negative impact that some technological practices have on the environment.

Among these institutions, there are many organizations spread all over the world working with viticulture and agrobiology, due to an increasing demand for organic grapes. Indeed, a considerable number of grape growers around the world have the commitment to produce organic products.

The international bibliography concerning the production of organic grapes covers different aspects of this field, such as those related to a) minimize the use of copper and its effect on the environment [1]; b) search alternative products to control different diseases [2]; c) control nematodes [3]; d) fertilization and mineral nutrition [4]; and e) the impact and evaluation of the organic viticulture [5-7].

Serra Gaúcha, the most important Brazilian viticultural region was also influenced by this scientific and technological development with the use of different agricultural inputs, such as fungicides, insecticides, herbicides, growth regulators and fertilizers.

This region is humid and hot during the summer time, climatic conditions that contribute to the development of diseases caused by a series of fungi species, such as anthracnose, downy mildew, Botrytis and grape ripe rot, which should be controlled by specific fungicides. The application of these products and other pesticides used in vineyards may result in residues on grapes. In addition, it is necessary to emphasize the possibility of causing problems to the environment - air, soil and groundwater contamination - and to the human being. Moreover, it is important to consider that organic products could also leave residues of undesirable substances used in vineyards. For example, the Bordeaux mixture the main fungicide used to control diseases in vineyards conducted according to the organic system in Brazil [8] -, contains copper in its formula. Therefore, it should be used carefully since high contents of this metal in soils and grapes could be harmful to humans and environment.

Considering the increasing awareness of the living conditions on Earth and, in particular, the health problems these pesticides may cause in many grape growers, a group of viticulturists of Serra Gaúcha is adopting organic procedures in their vineyards. In this way, some organic grapes are directed to the market to be consumed as table grape and another part goes to the industry to make still and sparkling wine, vinegar and jelly. However, most of them go to the grape juice industry to cope with the increasing demand for organic juices.

In general, grapevines produced by the organic system have lower yield than those from the conventional system. However, there is a lack of research data on this subject. A 3-year experiment was thus carried out with the objective of comparing grapevine yield components and physicochemical composition of the Isabel grape must conducted in both systems. 
Table 1. Parameters of Isabel grapevine yield components and grape must composition.

\begin{tabular}{|c|c|c|c|c|c|c|c|c|c|c|c|c|}
\hline \multirow{3}{*}{$\begin{array}{l}\text { Production } \\
\text { system }\end{array}$} & \multicolumn{3}{|c|}{ Yield components } & \multicolumn{8}{|c|}{ Grape must composition } & \multirow{3}{*}{ MG } \\
\hline & \multirow{2}{*}{$\begin{array}{c}\text { Number of } \\
\text { clusters/ } \\
\text { Vine }\end{array}$} & \multirow{2}{*}{$\begin{array}{c}\text { Weight/ } \\
\text { Cluster (g) }\end{array}$} & \multirow{2}{*}{$\begin{array}{l}\text { Yield/Vine } \\
(\mathrm{kg})\end{array}$} & \multirow{2}{*}{$\begin{array}{l}\text { Density } \\
(\mathrm{g} / \mathrm{mL})\end{array}$} & \multirow[b]{2}{*}{ Brix } & \multirow{2}{*}{$\begin{array}{c}\text { Titratable } \\
\text { acidity } \\
(\mathrm{meq} / \mathrm{L})\end{array}$} & \multirow{2}{*}{$\begin{array}{c}\text { Brix/ } \\
\text { Titratable } \\
\text { acidity }\end{array}$} & \multirow[b]{2}{*}{$\mathrm{pH}$} & $\mathrm{P}$ & $\mathrm{K}$ & $\mathrm{Ca}$ & \\
\hline & & & & & & & & & \multicolumn{3}{|c|}{$(\mathrm{mg} / \mathrm{L})$} & \\
\hline \multicolumn{13}{|l|}{ Organic } \\
\hline 2004 & 113 & 91.5 & 10.34 & 1.0833 & 19.6 & 68 & 38.4 & 3.32 & 77.7 & 1020.6 & 56.2 & 56.8 \\
\hline 2005 & 85 & 69.1 & 5.87 & 1.0839 & 19.5 & 66 & 39.4 & 3.22 & 66.6 & 996.4 & 74.2 & 49.9 \\
\hline 2006 & 58 & 111.9 & 6.49 & 1.0756 & 17.7 & 69 & 34.1 & 3.11 & 180.5 & 780.2 & 78.9 & 60.7 \\
\hline Mean & 85 & 90.8 & 7.57 & 1.0809 & 18.9 & 68 & 37.3 & 3.22 & 108.3 & 932.4 & 69.8 & 55.8 \\
\hline \multicolumn{13}{|l|}{ Conventional } \\
\hline 2004 & 207 & 109.9 & 22.76 & 1.0799 & 18.8 & 72 & 34.8 & 3.16 & 67.2 & 1031.3 & 62.7 & 53.3 \\
\hline 2005 & 179 & 78.0 & 13.96 & 1.0772 & 18.1 & 73 & 33.1 & 3.22 & 55.9 & 1072.8 & 71.2 & 45.3 \\
\hline 2006 & 127 & 100.9 & 12.81 & 1.0698 & 16.7 & 63 & 35.3 & 3.01 & 121.3 & 897.6 & 74.3 & 53.4 \\
\hline Mean & 171 & 96.3 & 16.51 & 1.0749 & 17.9 & 69 & 34.4 & 3.10 & 81.5 & 1000.6 & 69.4 & 50.7 \\
\hline
\end{tabular}

\section{Material and methods}

The vineyard was established in 1971 at Embrapa Uva e Vinho, Bento Gonçalves, Brazil. Isabel (syn. Isabella) grapevines (Vitis labrusca L.) were own-rooted, pergola trellised and spur pruned. The distance between east-westoriented rows was $3 \mathrm{~m}$ and within rows $2 \mathrm{~m}$. Therefore, the density was 1,666 grapevines/ha.

The experiment was carried out over three years, from 2004 to 2006, and the vineyard was divided in two uniform plots, one cultivated under conventional procedures and the other under organic principles. Each plot had 384 grapevines, which means 2,304 $\mathrm{m}^{2} /$ plot. The number of spurs an shoots left in each production system was according to the vigor of each grapevine. The leaves of all plants were exposed to sunlight to maximize photosynthesis and to enhance the air flow inside the vineyard.

In the conventional system, diseases were controlled by synthetic fungicides - mancozeb and metalaxyl - earlier in the growing season and, later, the Bordeaux mixture was used; weeds were controlled by glyphosate spraying. In the organic vineyard, lime sulfur was applied during the winter time and the Bordeaux mixture during all vegetative cycle; inter-rows were mechanically kept clean from weeds. The number of synthetic fungicides and Bordeaux mixture sprays varied depending on the climatic conditions of each year. Insecticides and fertilizers were not applied in the vineyards.

Variables related to yield components were evaluated during grape maturity, i.e., number of clusters/vine, yield/vine and weight/cluster. In both systems, these variables were evaluated in 60 grapevines with similar vigor. Then, 10 berries of each one of these 60 grapevines therefore a total of 600 berries per system - were sampled for physicochemical analysis, placed in plastic bags and soon taken to the laboratory where they were crushed. Next, the liquid phase was separated from the solid phase, centrifuged and analyzed.

The physicochemical variables evaluated were density, analyzed by a Paar digital aerometer with correction of temperature; Brix, by an Abbe refractometer with correction of temperature as well; $\mathrm{pH}$, by a Corning pHmeter; and titratable acidity, by titration [9]. The minerals $\mathrm{Ca}$ and $\mathrm{Mg}$ were analyzed by atomic absorption spectrophotometry and K by flame emission [10]; P, by UV/VIS spectrophotometry [10].
Mean data of the three years were submitted to correlation analysis and Principal Component Analysis (PCA).

\section{Results and discussion}

Grapevines cultivated under the organic production system had lower number of clusters/vine and lower yield/vine in the three years and weight/cluster lower in the two first harvests (Table 1). Considering the mean of three years, organic grapevines showed lower number of clusters/vine $(-50.29 \%)$, weight/cluster $(-5.71 \%)$ and yield/vine $(-54.15 \%)$.

These data show that there was a substantial difference between the grapevine yield because, on average, it decreased from $16.51 \mathrm{~kg} / \mathrm{vine}(27.51 \mathrm{t} / \mathrm{ha})$ in the conventional system to $7.57 \mathrm{~kg} / \mathrm{vine}(12.61 \mathrm{t} / \mathrm{ha})$ in the organic system. This was mainly due to the decrease in the number of clusters/vine, since the weight/cluster varied little. Indeed, the yield/vine and the number of clusters/vine had a significant correlation $(\mathrm{r}=0.95$; $\mathrm{p}<0.05)$ but yield/vine was not significantly correlated $(\mathrm{p}>0.05)$ to cluster weight, despite the fact that the weight/cluster of the organic grapes was slightly higher in the two first years and the average of three years. This result is in accordance with findings of previous work carried out with Merlot grapevines [11].

The decrease in the number of clusters/vine of the organic system, and consequently the decrease in the yield/vine, was mainly due to the overall grapevine behavior over three years which was dependent on the cultural practices used, such as those related to the control of diseases. The fungicide sprays were minimal in both production systems, but it seems that those with only Bordeaux mixture were less effective to control fungal diseases, especially downy mildew. This pathogen was probably most responsible for the reduced yield of organic grapevines, because it may cause damage - or death - of sprouts, shoots, individual flowers and inflorescences.

The average yields of this experiment, for both production systems, are similar to those reported by growers of the Serra Gaúcha viticultural region in the past years. As Isabel grapevines are moderately susceptible to fungal diseases, more resistant cultivars, such as Bordô (local name of the cv. Ives), another Vitis labrusca, could be recommended. Cultivars susceptible to most diseases, such as those of Vitis vinifera, are much more difficult to grow due to the climatic conditions of this region. 


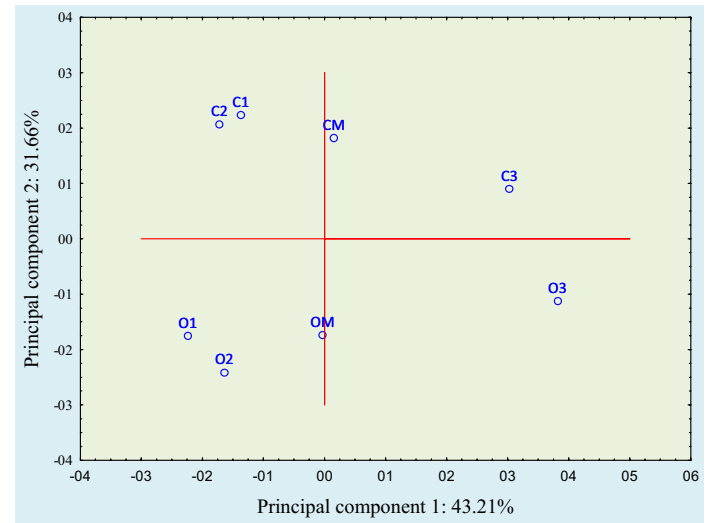

Figure 1. Projection of the organic and conventional production systems on the principal components formed by the planes $1 \times 2$. Legend: $\mathrm{O}=$ organic system; $\mathrm{C}=$ conventional system, $\mathrm{M}=$ mean, $1=2004,2=2005,3=2006$.

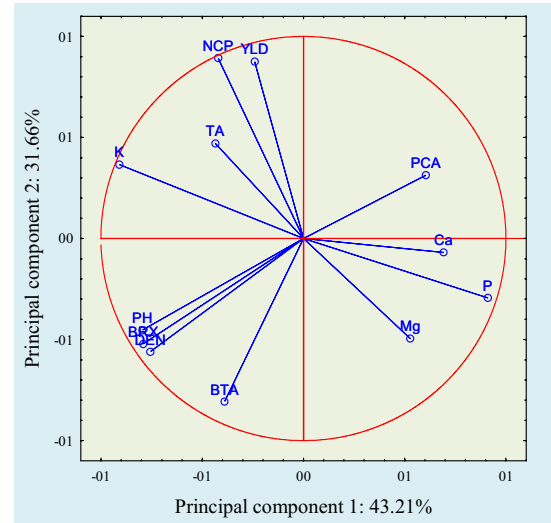

Figure 2. Projection of the variables on the principal components formed by the planes $1 \times 2$. Legend: $\mathrm{NGP}=$ number of clusters/vine, YLD = yield/vine, PCA = weight/cluster, BRX = Brix, $\mathrm{DEN}=$ density, $\mathrm{PH}=\mathrm{pH}, \mathrm{TA}=$ titratable acidity; $\mathrm{BTA}=$ Brix/Titratable acidty ratio, $\mathrm{P}=$ phosphorus, $\mathrm{K}=$ potassium, $\mathrm{Ca}=$ calcium, $\mathrm{Mg}=$ magnesium .

As the yield of organic grapevines was lower (Table 1), the average composition of organic grape musts showed higher values for most variables evaluated, i.e., density $(+0.56 \%)$, Brix $(+5.59 \%)$, Brix/titratable acidity ratio $(+8.43 \%)$ and $\mathrm{pH}(+3.87 \%)$. However, the titratable acidity was lower $(-1.45 \%)$ despite the fact there was no significant correlation $(\mathrm{p}<0.05)$ between $\mathrm{pH}$ and titratable acidity. The $\mathrm{P}(+32.88 \%)$ and $\mathrm{Mg}(+10.06 \%)$ concentrations were also higher in the grape musts of the organic system, which was most likely due to the decrease in the grapevine yield rather than to the effect of the organic practices used. Nevertheless $\mathrm{K}$ had lower values $(-6.82 \%)$ and Ca varied little (Table 1).

The difference between the yield of conventional and organic grapevines was of $14.90 \mathrm{t} / \mathrm{ha}$ as the Brix was of only 1 (mean of 18.9 in the organic must and 17.9 in the conventional must). This shows the capacity of these vines have to produce and accumulate sugar in the grape berries. There are many works relating yield and total soluble solids in grapes. Some show that there is no direct relationship between them [12] and others found that the increase of sugar in grape is proportionally low compared to the reduction of productivity [13]. But, most works show that the higher the yield, the lower the sugar concentration in grape berries [14]. The differences found by these workers may be explained by several factors, such as cultural practices used in vineyards, soil characteristics, capacity of each grapevine, source/sink relationship and partition of metabolites in different plant organs.

The parameters of all variables of both production systems were submitted to Principal Component Analysis. Considering the mean of three years, results show that the two main components were responsible for $74.87 \%$ of the total variation ( $\mathrm{PC} 143.21 \%$ and $\mathrm{PC} 231.66 \%$ ). This means that there were other principal components responsible for the observed variation in the yield components of the grapevines and in the grape must composition. The PCA shows that the average yield of the grapevines cultivated under the organic and conventional systems are in opposite positions on PC2, where conventional grapevines had higher values for yield components. It also shows that these vines had lower parameters for the variables evaluated in the grape must (Figs. 1 and 2).

\section{Conclusion}

Grapevines cultivated under the organic system had about $50 \%$ lower yield than the conventional one, which represents higher cost $/ \mathrm{kg}$ of produced grape. This increase in cost should be transferred to the industries and consequently to consumers. However, grapes were slightly sweeter, less acid and had, as those from the conventional system, a desirable sugar/acid balance for the Brazilian taste. Thus, the Isabel grapes produced by the organic system have suitable composition to make quality grape juice. It should be remembered that synthetic pesticides are not allowed to be used in the organic system, which may result in grapes and grape juices free of these products and that is why it may impact less the environment and the human being.

The author thanks colleagues of Embrapa Uva e Vinho for their kind collaboration during the three years this experiment was conducted.

\section{References}

[1] S. Dagostin, H-J. Schärer, I. Pertot, L. Tamm. Crop Prot., 30, 7 (2011)

[2] P. Crisp, T.J. Wicks, D. Breuer, E.S. Scott. Aust. J. Grape and Wine Res., 12, 3 (2006)

[3] P. Coll, E. Le Cadre, C. Villenave. Nematology, 14, 7 (2012)

[4] P. Coll, E. Le Cadre, E. Blanchart, Ph. Hinsinger, C. Villenave. Appl. Soil Ecol., 50, p.37-44 (2011)

[5] J.R. Reeve, L. Carpenter-Boggs, J.P. Reganold, A.L. York, G. McGourty, L.P. McCloskey. Am. J. Enol. Vitic., 56, 4 (2005)

[6] G. Fragoulis, M. Trevisan, A. Di Guardo, A. Sorce, M. van der Meer, F. Weibel, E. Capri. J. Environ. Qual., 38, 2 (2009)

[7] M. Raviv. Chronica Hortic., 50, 2 (2010)

[8] A. Miele. Pesq. Agropec. Bras., 22, 9-10 (1987)

[9] J. Ribéreau-Gayon, E. Peynaud, P. Ribéreau-Gayon, P. Sudraud. Traité d'œnologie. Sciences et techniques du vin (Dunod, Paris, 1982) 
[10] P. Ribéreau-Gayon, Y. Glories, A. Moujean, D. Dubourdieu. Traité d'œnologie. 2. Chimie du vin, stabilization e traitements (Dunod, Paris, 1998)

[11] A. Miele, F. Mandelli. Rev. Bras. Frutic., 34, 4 (2012)
[12] M. Keller., L.J. Mills., R.L. Wample, S.E. Spayd. Am. J. Enol. Vitic., 56, p. 91-103 (2005)

[13] A. Miele, L.A. Rizzon. Rev. Bras. Frutic., 35, 4 (2013)

[14] I. Dami, D. Ferree, A. Prajitna, D. Scurlock. HortSci., 41, p. 586-588 (2006) 